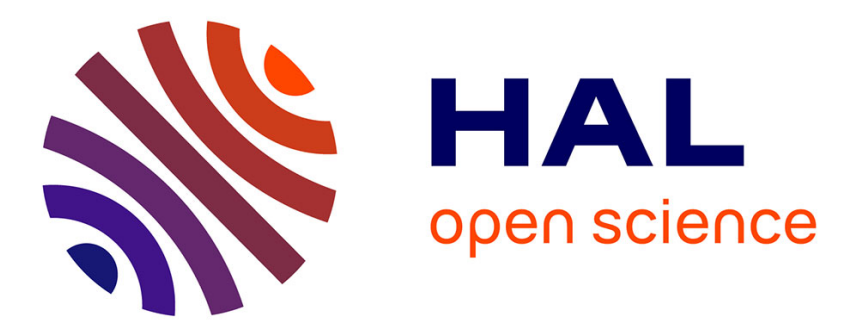

\title{
Identification of Bombus species based on wing venation structure
}

Peter Kozmus, Meta Virant-Doberlet, Vladimir Meglič, Peter Dovč

\section{To cite this version:}

Peter Kozmus, Meta Virant-Doberlet, Vladimir Meglič, Peter Dovč. Identification of Bombus species based on wing venation structure. Apidologie, 2011, 42 (4), pp.472-480. 10.1007/s13592-011-0037-5 . hal-01003570

\section{HAL Id: hal-01003570 \\ https://hal.science/hal-01003570}

Submitted on 1 Jan 2011

HAL is a multi-disciplinary open access archive for the deposit and dissemination of scientific research documents, whether they are published or not. The documents may come from teaching and research institutions in France or abroad, or from public or private research centers.
L'archive ouverte pluridisciplinaire HAL, est destinée au dépôt et à la diffusion de documents scientifiques de niveau recherche, publiés ou non, émanant des établissements d'enseignement et de recherche français ou étrangers, des laboratoires publics ou privés. 


\title{
Identification of Bombus species based on wing venation structure
}

\author{
Peter Kozmus ${ }^{1}$, Meta Virant-Doberlet ${ }^{2}$, Vladimir Meglič ${ }^{1}$, Peter Dovč ${ }^{3}$ \\ ${ }^{1}$ Agricultural Institute of Slovenia, Hacquetova 17, Ljubljana, Slovenia \\ ${ }^{2}$ National Institute of Biology, Večna pot 111, Ljubljana, Slovenia \\ ${ }^{3}$ Biotechnical Faculty, University of Ljubljana, Groblje 3, Domžale, Slovenia
}

Received 2 February 2010 - Revised 3 August 2010 - Accepted 4 August 2010

\begin{abstract}
About 250 bumblebee species in 15 subgenera are known in the world. Identification of some species is difficult due to small morphological differences. In this study, wing venation patterns were analysed to obtain characters for species identification. Four hundred and sixty-nine bumblebees from 121 localities in Slovenia and 61 imported individuals were included in the analyses. The coordinates of 19 vein junctions on the forewings were measured and used in the calculation of 37 wing characters. Based on discriminate method, more than $97 \%$ of all analysed bumblebees were assigned to the correct species. The most informative characters were angles J16, A4 and discoidal shift. Wing venation pattern also differed between autochthonous and imported Bombus terrestris individuals.
\end{abstract}

bumblebees / identification / wing venation / Slovenia

\section{INTRODUCTION}

The world bumblebee fauna consists of approximately 250 species (Williams 1998). All species of the genus Bombus have been assigned to 15 subgenera (Williams et al. 2008). The majority of these species are known as true bumblebees. The remaining 45 species are known as cuckoo bumblebees, and belong to the subgenus Psithyrus (Pedersen 2002).

Correct species identification is very important especially when bumblebee species are used as an environment indicator. As a genus, Bombus is morphologically monotonous (Michener 1990), and species are difficult to identify due to variations in colour, size and morphology (Krüger 1958; Pekkarinen et al. 1979; Reinig 1981). Early classifications depended mostly on

Corresponding author: P. Kozmus, peter.kozmus@kis.si

Manuscript editor: Marla Spivak colour patterns (Dalla Torre 1980), but these were generally regarded as being of limited value, particularly since most species exhibit considerable colour variation within and between populations. Also, there is often convergent evolution of coat colour driven by Mullerian mimicry (Plowright and Owen 1980; Williams 2007). Many morphological keys exist for bumblebee determination (e.g. Faester 1959; Løken 1973; Milliron 1973; Alford 1975; Delmas 1976; Erlandsson 1979; Svensson 1979; Løken 1984; Rasmont 1984; Prys-Jones and Corbet 1991; Amiet 1996; Bertsch 1997); however, only the species from limited geographic regions are included in these keys. Species are often distinguished only by small differences in morphology and therefore, a lot of practice is needed for correct determination.

The subgenus Bombus with the European species Bombus terrestris, Bombus lucorum, Bombus cryptarum, Bombus magnus, Bombus maderensis and Bombus sporadicus varies so 
little that only typical specimens and queens can be identified (Pedersen 2002). Despite considerable intraspecific variation, studies based on morphology (Krüger 1958; Pekkarinen et al. 1979; Rasmont 1984), cross-breeding experiments (De Jonghe and Rasmont 1983), enzyme electrophoretic data (Scholl and Obrecht 1983; Pamilo et al. 1987) and analysis of the compounds of the secretion from male labial glands (Bertsch 1997) confirmed the existence of these species. Also, comparison of mtDNA sequences within the subgenus Bombus showed that species can be characterised using specific mtDNA polymorphisms (Pedersen 2002; Murray et al. 2008). However, reliable identification based exclusively on morphological traits is still problematic and numerous discrepancies in classification and identification are still present.

In the present study, we examined the wing venation patterns of 18 bumblebee species to determine if this approach is sufficient for species identification and determination. Wing venation characters have been applied in morphometric analyses and taxonomic classification of the honeybee Apis mellifera L. (Ruttner et al. 1978). Compared to honeybees, bumblebees have similar wing venation structure (differences exist only in one vein junction) and therefore the same wing characters could be used for species determination. We also assessed the suitability of this approach to distinguish specimens of imported B. terrestris from the Netherlands, which are used for commercial pollination, from native specimens of the same species from Slovenia.

\section{MATERIALS AND METHODS}

\subsection{Collecting samples and identification}

Altogether, 530 specimens (workers and queens) were analysed (Table I). While in some species (e.g. Bombus pascuorum), many specimens were found and included in the analyses; in others (e.g. Bombus barbutellus), only few specimens were collected and analysed. Four hundred and sixty-nine specimens were collected from different sites in Slovenia (Figure 1) and 61 specimens (B. terrestris) were from commercial colonies imported from the Netherlands. All specimens were collected over three years, 2004-2006, from June through September each year. Species identification was made using morphological keys (Amiet 1996; Prys-Jones and Corbet 1991). Before and after analysis, specimens were stored at $-80^{\circ} \mathrm{C}$.

\subsection{Wing venation analysis}

The right side forewing was removed from each specimen, attached to paper and scanned into a digital image. Coordinates of 19 vein junctions (Figure 2) were used for analysis, following Ruttner (1988), to obtain 37 wing characters (Tables II and III). For calculating wing characters, BeeWings 1.20 (Farny 1999) was used.

All data were analysed with the statistical programme SAS (version 8.02). Analysis of variance was calculated for 37 characters. Following discriminate analysis, based on Mahalanobis distances, each specimen was assigned to a group. In addition, canonical discriminate analysis was performed and three components with the most variability were calculated. 3D graphs were constructed using the KyPlot programme (ver. 2.0 beta; Yoshioka 2001). Finally, multiple variance analysis based on LSD (least significant difference) test was performed and statistical differences between species in wing venation characteristics were calculated.

\section{RESULTS}

Explained variability $\left(R^{2}\right)$ and values of statistical significance $(p)$ for each of 37 characters are shown in Table IV. The highest $R^{2}$ was calculated for angles J16 (0.64), A4 $(0.62)$ and for the discoidal shift $(0.60)$. The least informative were angles $\mathrm{O} 26(0.16)$ and A1 (0.15). Altogether 30 characters had $R^{2}$ above 0.30 and for subsequent calculations only the most informative characteristics were used (Table IV).

Using discriminate analysis, all specimens in 13 out of 18 species were classified into correct species groups (Figure 3). In five species, a few specimens were classified incorrectly. The highest error rate was found in Bombus sylvarum, where two out of 17 specimens were classified 
Table I. Number of specimens of each bumblebee species included in the wing venation analyses.

\begin{tabular}{lclc}
\hline \multicolumn{1}{c}{ Species } & Number & \multicolumn{1}{c}{ Species } & Number \\
\hline B. pascuorum (w) & 102 & B. pratorum (w) & 16 \\
B. lapidarius (w) & 65 & B. wurfleinii (w) & 12 \\
B. terrestris (imported) (w) & 61 & B. soroeensis (w) & 9 \\
B. lucorum (w) & 56 & B. hypnorum (w) & 8 \\
B. hortorum (w) & 52 & B. monticola (w) & 7 \\
B. humilis (w) & 40 & B. argillaceus (w) & 6 \\
B. terrestris (w) & 30 & B. sylvestris (q) & 6 \\
B. ruderarius (w) & 20 & B. rupestris (q) & 5 \\
B. sylvarum (w) & 17 & B. barbutellus (q) & 2 \\
B. bohemicus (q) & 16 & Total & 530 \\
\hline
\end{tabular}

$w$ workers, $q$ queens

incorrectly $(11.8 \%)$, while in native $B$. terrestris (30), Bombus hortorum (52), Bombus humilis (40) and B. pascuorum (102), only one specimen was assigned incorrectly. Analysis also revealed differences between Slovenian and imported populations of $B$. terrestris. Two native specimens were assigned to the group of imported B. terrestris and similarly, three imported bumblebees out of 61 were classified in the native population.

Using canonical discriminate analysis, three variables were created to separate the species into groups based on wing morphology. Due to high degree of overlap, plotting all 18 species in one graph showed only basic differences between species. To demonstrate that morphologically similar species can have significantly different wing morphology, we grouped together only the most morphologically similar species (Figure 4). A comparison between B. lucorum and $B$. terrestris is shown in Figure 4a. Although both species are morphologically very similar in other characters, the specimens fell into separate groups that overlapped only slightly. Species

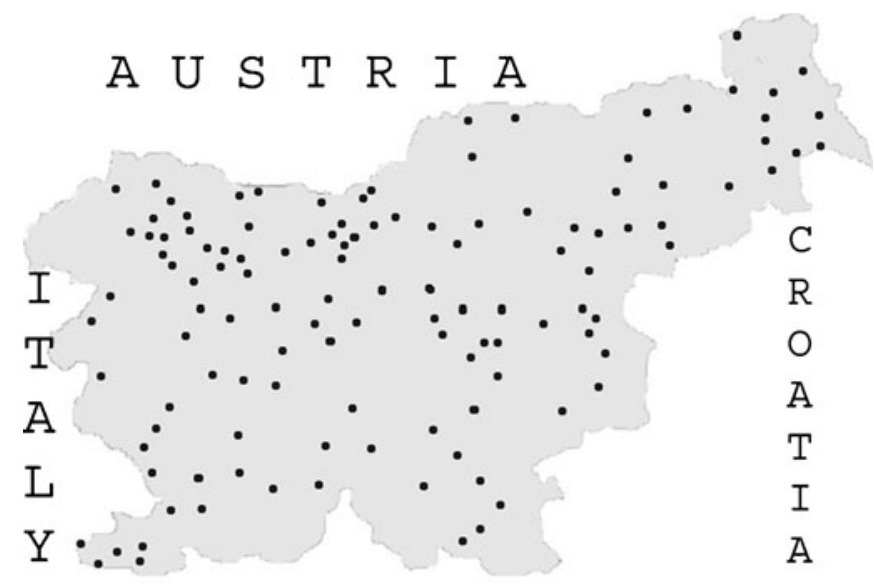

Figure 1. Dots indicate sites in Slovenia where bumblebees were collected for analyses. 


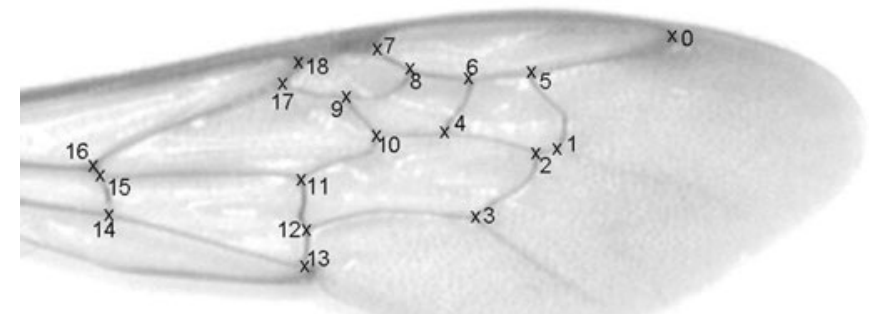

Figure 2. Right bumblebee forewing with 19 measured points at vein junctions.

Bombus lapidarius, Bombus monticola, Bomobus ruderarius, Bombus rupestris and Bombus wurfleinii are all black with red pile on the terminus of the abdomen, but based on wing venation these species can be discriminated (Figure 4b). A comparison between $B$. hortorum, $B$. lapidarius, B. lucorum and B. pascuorum is shown in Figure 4c. Differences among species are clearly seen; only specimens $B$. lucorum and B. lapidarius overlap. Again, analysis revealed differences between autochthonous and imported populations of $B$. terrestris, although populations overlapped in the middle (Figure 4d).

Difference in wing venation characters and statistical significance among bumblebees species, based on $t$ test and LSD criterion are shown in Table V. Four species (B. humilis, $B$. lucorum, Bombus pratorum and B. terrestris) and the group of the imported $B$. terrestris were significantly different from all other species.
Also, the difference in wing venation between autochthonous and imported $B$. terrestris was significant. However, differences among $B$. barbutellus and the other nine species were not significant.

\section{DISCUSSION}

Nearly all measured wing pattern characters were informative (average $R^{2}=0.43$ ). Unlike in honey bee species and subspecies determination, the most informative character for Bombus determination was not cubital index (Ruttner 1988), but angles J16, A4 and discoidal shift. The least informative characters were angles A1 and $\mathrm{O} 26$. Angle $\mathrm{O} 26$ is related to a vein junction where differences between honeybee and bumblebee wings occur, and therefore a low informativeness was expected. In angle $\mathrm{A} 1$, one length is too small for accurate measurements

Table II. Measured angles, lengths and indices of the vein patterns and their boundary points.

\begin{tabular}{|c|c|c|c|c|c|c|c|}
\hline Angles & Points & Angles & Points & Length & Points & Index & Points \\
\hline A1 & $2,1,4$ & $\mathrm{~J} 10$ & $6,9,10$ & Radial field & 0,7 & Cubital (CI) & $2 ; 4 / 1 ; 2$ \\
\hline A4 & $4,1,5$ & $\mathrm{~J} 16$ & $8,9,18$ & A & 2,4 & Precubital (PCI) & $4 ; 9 / 8 ; 10$ \\
\hline B3 & $1,4,3$ & K19 & $12,11,14$ & B & 1,2 & Dumb-bell (DBI) & $1 ; 4 / 5 ; 6$ \\
\hline B4 & $1,4,5$ & L13 & $5,7,6$ & $\mathrm{C}$ & 3,4 & Radial (RI) & $0,7,3$ \\
\hline $\begin{array}{l}\text { D7 } \\
\text { E9 }\end{array}$ & $\begin{array}{l}4,3,13 \\
6,5,10\end{array}$ & $\begin{array}{l}\text { M17 } \\
\text { N23 }\end{array}$ & $\begin{array}{l}7,8,18 \\
9,18,17\end{array}$ & $\begin{array}{l}\text { D } \\
\text { Inner length }\end{array}$ & $\begin{array}{l}11,15 \\
1,14\end{array}$ & $\begin{array}{l}\text { Surface of } 6 \text { fields } \\
\text { (AREA6) }\end{array}$ & $\begin{array}{l}1,2,3,12,13, \\
14,15,16,17,\end{array}$ \\
\hline G7 & $3,13,4$ & $\mathrm{O} 26$ & $15,14,16$ & Inner width & 7,13 & & \\
\hline $\begin{array}{l}\text { G18 } \\
\mathrm{H} 12\end{array}$ & $\begin{array}{l}12,13,14 \\
11,10,12\end{array}$ & Q21 & $11,16,17$ & $\begin{array}{l}\text { Discoidal schift } \\
\text { (DisA), (DisD) }\end{array}$ & $0,7,3$ & & \\
\hline
\end{tabular}

In angles, the vertex is denoted by the second number in the series and the first and last numbers are the end points of line segments 
Table III. Measured cells in the vein patterns and their boundary points.

\begin{tabular}{llc}
\hline \multicolumn{1}{c}{ CELL } & \multicolumn{1}{c}{ Points } & \multicolumn{1}{c}{ Measured lengths } \\
\hline Cub cell 1 (CUB1) & $7,8,9,17,18$ & $7-8,7-9,7-18,8-9,9-17,9-18,17-18$ \\
Cub cell 2 (CUB2) & $4,6,8,9,10$ & $4-6,4-10,6-8,6-10,8-9,8-10,9-10$ \\
Cub cell 3 (CUB3) & $1,2,4,5,6$ & $1-2,1-5,2-4,2-5,4-5,4-6,5-6$ \\
Discoidal cell 1 (DIS1) & $9,10,11,16,17$ & $9-10,9-11,9-17,10-11,11-16$, \\
& & $11-17,16-17$ \\
Discoidal cell 2 (DIS2) & $2,3,12,11,10,4$ & $2-3,2-4,3-4,3-10,3-11,3-12$, \\
& & $4-10,10-11,11-12$ \\
Brachial cell (BRA1) & $11,12,13,14,15,16$ & $11-12,11-16,12-13,12-16,13-14$, \\
& & $13-15,13-16,14-15,15-16$ \\
\hline
\end{tabular}

and low informativeness was a consequence of a high scoring error.

Results of the discriminate analyses were very promising. Based on this method, more than 97\% of analysed bumblebees were assigned to the correct species. In 13 species, all specimens $(100 \%)$ were correctly assigned. With some optimization and programme for wing measuring adjustments this method will undoubtedly yield even better results. The results may further improve

Table IV. Values of explained variability $\left(R^{2}\right)$ and statistical significance $(p)$ calculated by analysis of variance.

\begin{tabular}{cccccc}
\hline Characteristics & $R^{2}$ & $p$ value & Characteristics & $R^{2}$ & $p$ value \\
\hline J16 & 0.6382 & $<0.0001$ & N23 & 0.4489 & $<0.0001$ \\
A4 & 0.6191 & $<0.0001$ & Area6 & 0.4479 & $<0.0001$ \\
DisD & 0.6030 & $<0.0001$ & BRA1 & 0.4203 & $<0.0001$ \\
DBI & 0.5840 & $<0.0001$ & A & 0.4151 & $<0.0001$ \\
K19 & 0.5831 & $<0.0001$ & B4 & 0.3943 & $<0.0001$ \\
L13 & 0.5746 & $<0.0001$ & CI & 0.3942 & $<0.0001$ \\
CUB3 & 0.5493 & $<0.0001$ & DIS1 & 0.3820 & $<0.0001$ \\
D7 & 0.5456 & $<0.0001$ & RI & 0.3758 & $<0.0001$ \\
G7 & 0.5283 & $<0.0001$ & Inner width & 0.3750 & $<0.0001$ \\
H12 & 0.5223 & $<0.0001$ & PCI & 0.3677 & $<0.0001$ \\
D & 0.5117 & $<0.0001$ & CUB2 & 0.3613 & $<0.0001$ \\
CUB1 & 0.5067 & $<0.0001$ & Q21 & 0.2620 & $<0.0001$ \\
DisA & 0.4956 & $<0.0001$ & G18 & 0.2475 & $<0.0001$ \\
B3 & 0.4941 & $<0.0001$ & E9 & 0.2444 & $<0.0001$ \\
DIS2 & 0.4885 & $<0.0001$ & J10 & 0.1965 & $<0.0001$ \\
Inner length & 0.4884 & $<0.0001$ & M17 & 0.1730 & $<0.0001$ \\
Radial field & 0.4765 & $<0.0001$ & O26 & 0.1588 & $<0.0001$ \\
C & 0.4752 & $<0.0001$ & A1 & 0.1546 & $<0.0001$ \\
B & 0.4598 & $<0.0001$ & & & \\
& & & &
\end{tabular}

Characters in shadowed fields were omitted from further analysis 


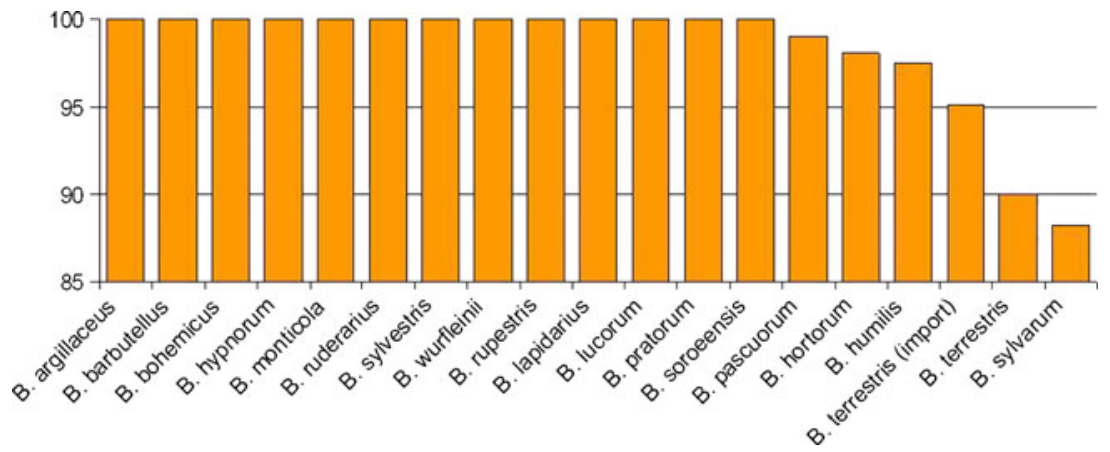

Figure 3. Percentage (\%) of correctly assigned specimen based on discriminate analysis.

if more specimens could have been included in the analyses, specifically where only a few bees represented a species (e.g. B. barbutellus). The method also appears useful to compare or distinguish populations of the same species, because we distinguished imported $B$. terrestris individuals from the native Slovenian $B$. terrestris population.

Based on these results, bumblebee wing venation pattern is an appropriate tool for species determination. The method is especially
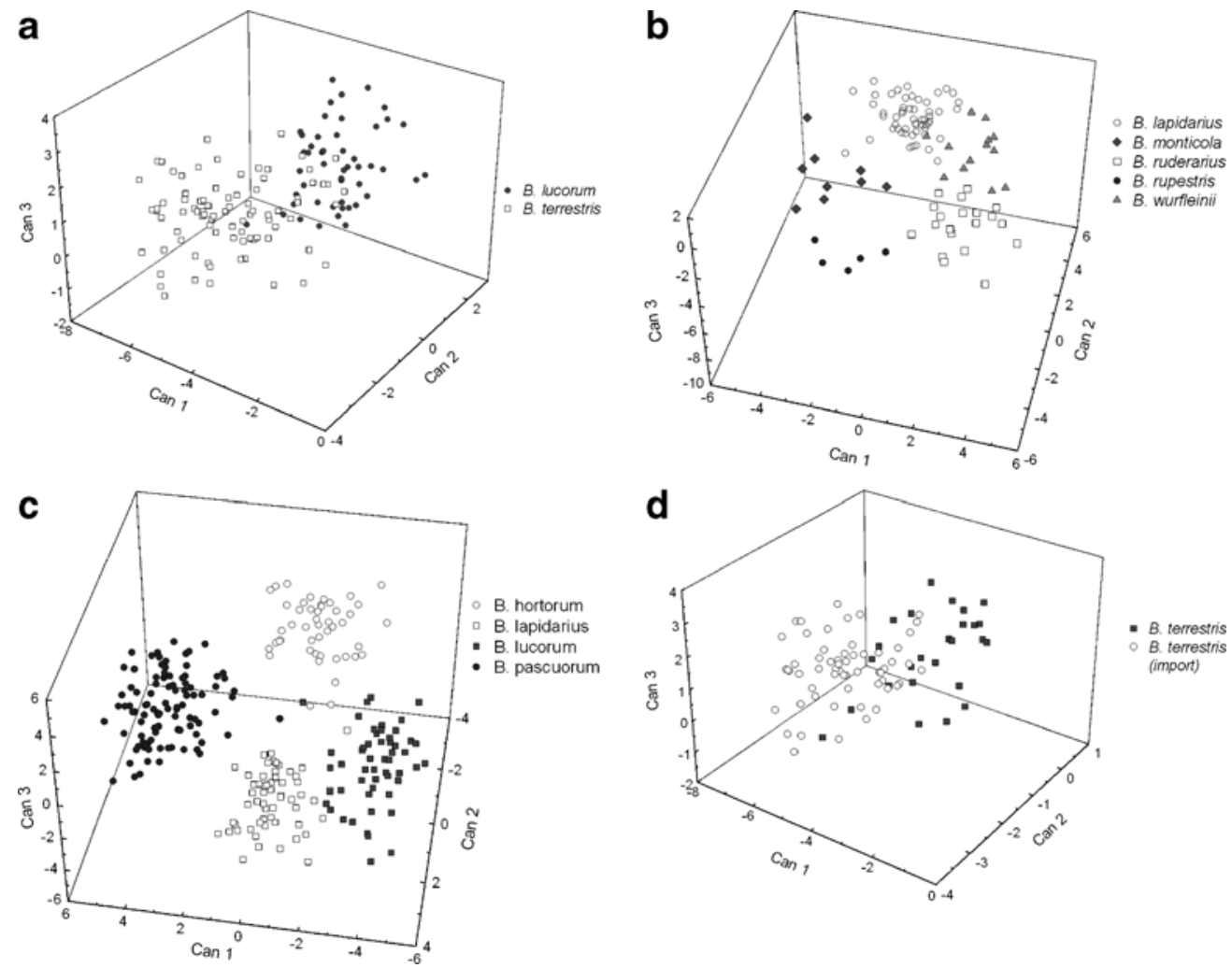

Figure 4. Differences in wing venation pattern based on discriminate analysis between different bumblebees species. 
useful for species which, based on others morphological characteristics, are hard to determine (e.g. B. terrestris, B. lucorum). Using a full classical morphological approach can be time-consuming and ultimately results in the destruction of the specimen; therefore, the use of a single forewing for species determination is more appropriate if many specimens must be determined and the material is to be retained in an entomological collection. This method is not very expensive, compared to genetic analyses, due to low-capital investment needed (scanner, computer and software). It is also appropriate for researchers who do not have enough experience with bumble bee taxonomy as they could use wing venation analysis to confirm morphological identification.

\section{Identification des espèces de bourdon (Bombus) à partir de la structure des nervures alaires.}

bourdon / identification / Slovénie / nervures alaires

\section{Bestimmung von Bombus-Arten anhand der Struktur des Flügelgeäders.}

\section{Hummeln / Artbestimmung / Flügelgeäder / Slowenien}

\section{REFERENCES}

Alford D.V. (1975) Bumblebees. London, Davis-Poynter: 352 str.

Amiet, F. (1996) Hymenoptera: Apidae, 1.Teil. Insecta helvetica 12, 1-98

Bertsch, A. (1997) Abgrenzung der Hummel-Arten Bombus cryptarum und B. lucorum mittels männlicher Labialdrüsen-Sekrete und morphologischer Merkmale (Hymenoptera; Apidae). Entomol. Gen. 22, 129-145

Dalla Torre, K.W. (1980) Unsere hummel-(Bombus) Arten. Naturhistoriker 2, 40-41

De Jonghe, R., Rasmont, P. (1983) Kreuzungsexperiment mit Hummeln des Genus Bombus Latreille Sensu Stricto (Hymenoptera; Apidae). Phegea 11, 7-10

Delmas, R. (1976) Contribution à l'étude de la faune française des Bombinae (Hymenoptera, Apoidea, Bombidae). Ann. Soc. Entomol. Fr. (Nouvelle serie) 12, 247-290
Erlandsson, A. (1979) Bombus canariensis Pérez, 1895 n. stat and Bombus maderensis n. sp. from the Macaronesian Islands. Entomol. Scand. 10, 187192

Faester, K. (1959) In Dänemark getroffene Arten von Bombus und Psithyrus (Hym., Apidae). Entomol. Medd. 29, 152-153

Farny R. (1999) BeeWings v. 1.20.902.56 computer program distributed by the author and Bee research institute in Dol. Czech Republic.

Krüger, E. (1958) Phaenoanalytische studien an einigen arten der untergattung Terrestribombus $\mathrm{O}$. Vogt (Hymenoptera, Bombidae) III. Tijdschr. Entomol. 101, 283-344

Løken, A. (1973) Studies on Scandinavian bumblebees (Hymenoptera, Apidae). Norsk entomologisk tidsskr. 20, 1-218

Løken, A. (1984) Scandinavian species of the genus Psithyrus Lepeletier (Hymenoptera: Apidae). Entomol. Scan. (supplement) 23, 1-45

Michener, C.D. (1990) Classification of the Apidae. University of Kansas Science Bull. 54, 75-164

Milliron, H.E. (1973) A Monograph of the Western Hemisphere Bumblebees (Hymenoptera: Apidae: Bombinae). II. The Genus Megabombus Subgenus Megabombus. Mem. Entomol. Soc. Can. 89, 81237

Murray, T.E., Fitzpatrick, U., Brown, M.J.F., Paxton, R.J. (2008) Cryptic species diversity in a widespread bumble bee complex revealed using mitochondrial DNA RFLPs. Conserv. Genet. 9, 653-666

Pamilo, P., Pekkarinen, A., Varvio, S.L. (1987) Clustering of bumblebee subgenera based on interspecific genetic relationships (Hymenoptera: Apidae: Bombus and Psithyrus). Ann. Zool. Fenn. 24, 19-27

Pedersen, B.V. (2002) European bumblebees (Hymenoptera: Bombini) - phylogenetic relationship inferred from DNK sequences. Insect. Syst. Evol. 33, 361386

Pekkarinen, A., Varvio-Aho, S.L., Pamilo, P. (1979) Evolutionary relationships in northern European Bombus and Psithyrus species (Hymenoptera: Apidae) studied on the base of allozymes. Ann. Entomol. Fenn. 45, 77-80

Plowright, R.C., Owen, R.E. (1980) The evolutionary significance of bumble bee colour patterns - a mimetic interpretation. Evolution 34, 622-637

Prys-Jones, O.E., Corbet, S.A. (1991) Bumblebees. Naturalists Handbooks 6. Richmonds Publishing Co, Slough, England. 92 str

Rasmont, P. (1984) Les bourdons du sous-genre Bombus Latreille sensu stricto en Europe Occidentale et Centrale (Hymenoptera, Apidae). Spixiana 7, 135-160

Reinig, W.F. (1981) Synopsis der in Europa nachgewiesen Hummel-und schmarotzerhummelarten. Spixiana 4, 159-164 
Ruttner, F. (1988) Biogeography and taxonomy of honeybees, pp. 251-257. Springler-Verlag, Berlin

Ruttner, F., Tassencourt, L., Louveaux, J. (1978) Biometrical-statistical analsis of the geographical variability of Apis mellifera L. Apidologie 9, 363381

Scholl, A., Obrecht, E. (1983) Enzymelektrophoretische Untersuchungen zur Artsabgrenzung im Bombus lucorum-Komplex (Apidae, Bombini). Apidologie 14, 65-78

Svensson, B.G. (1979) Pyrobombus lapponicus auct. in Europe recognized as two species: P. lapponicus (Fabricius, 1793) and P. monticola (Smith, 1849) (Hymenoptera, Apoidea, Bombinae). Entomol. Scan. 10, 275-296
Williams, P.H. (1998) An annotated checklist of bumble bees with an analysis of patterns of description (Hymenoptera: Apidae, Bombini). Bull. Brit. Museum (Natural History) Entomol. 67, 79-152

Williams, P.H. (2007) The distribution of bumblebee colour patterns world-wide: possible significance for thermoregulation, crypsis, and warning mimicry. Biol. J. Linn. Soc. 92, 97-118

Williams, P.H., Cameron, S.A., Hines, H.M., Cederberg, B., Rasmont, P. (2008) A simplified subgeneric classification of the bumblebees (genus Bombus). Apidologie 39, 46-74

Yoshioka K. (2001) KyPlot v. 2.0 computer program distributed by the author at http://kyplot.software. informer.com/2.0\%. Accesseed 12 May 2008). 